\title{
PENYELESAIAN DEBITUR WANPRESTASI DALAM PERJANJIAN KREDIT JAMINAN FIDUSIA MENURUT UNDANG-UNDANG NO. 42 TAHUN 1999 TENTANG JAMINAN FIDUSIA
}

\author{
Asuan \\ Fakultas Hukum Universitas Palembang \\ Email: asuan.okay@gmail.com
}

\begin{abstract}
Type of research in doctrinal law or better known as normative legal research which is also called normative juridical (legal research) concerning the legal issues at hand. The approach to the law (statue approach) is carried out by examining the laws and regulations. In writing with primary and secondary data obtained from library materials namely Law No. 42 of 1999 concerning Fiduciary Guarantees, Law No. 10 of 1998 concerning Banking, Government Regulations, Civil Code, KUH Trade and literature, lecture materials and other sources related to credit agreements with fiduciary guarantees and problems in particular. In granting credit with fiduciary guarantees through the stages of the procedure for credit application and the making of a fiduciary deed at the notary who is registered with the Office of Fiduciary Registration to provide legal certainty for creditors (banks). Credit settlement process if the debtor is malicious, the bank is based on a substitution power of attorney from the debtor made a notariil Fiduciary deed and registered with the Fiduciary Office, the debtor makes a sale under the hands, the sale of collateral is voluntary, the result is submitted to the bank to repay the loan, the bank can conduct the auction in general and through the Court.
\end{abstract}

keyword: fiduciary guarantee; default debtor

\section{ABSTRAK}

Tipe penelitian penelitian hukum doktrinal atau yang lebih dikenal dengan penelitian hukum normatif yang disebut juga yuridis normatif (legal research) mengenai isu hukum yang sedang dihadapi . Pendekatan undang-undang (statue approach) dilakukan dengan menelaah peraturan perundangan. Dalam penulisan dengan data primer dan sekunder diperoleh dari bahan-bahan kepustakaan yaitu Undang-Undang No. 42 Tahun 1999 tentang Jaminan Fidusia, Undang-Undang No. 10 Tahun 1998 tentang Perbankan, Peraturan Pemerintah, KUH Perdata, KUH Dagang dan literatur-literatur, bahan perkuliahan serta sumber lainnya yang berhubungan dengan perjanjian kredit dengan jaminan fidusia dan permasalahan pada khususnya. Dalam pemberian kredit dengan jaminan fidusia melalui tahapan prosedur permohonan kredit dan dibuatnya akta fidusia di notaris yang didaftarkan ke Kantor Pendaftaran Fidusia unutk memberikan kepastian hukum bagi kreditur (bank). Proses penyelesaian kredit jika debitur wanpreatasi maka bank berdasarkan surat kuasa substitusi dari debitur dibuat akte Fidusia notariil dan didaftarkan ke Kantor Fidusia yaitu debitur melakukan penjualan di bawah tangan, penjualan jaminannya secara sukarela, yang hasilnya diserahkan kepada bank untuk melunasi kredit tersebut, bank dapat melakukan pelelangan secara umum dan melalui lembaga Pengadilan.

Kata kunci : jaminan fidusia; debitur wanprestasi

\section{PENDAHULUAN}

$$
\text { Perkembangan ekonomi }
$$
nasional dewasa ini menunjukkan arah yang semakin menyatu dengan ekonomi regional dan internasional yang dapat menunjang sekaligus dapat berdampak kurang menguntungkan. Sementara itu, perkembangan perekonomian nasional senantiasa bergerak cepat dengan tantangan yang semakin kompleks. Oleh karena itu, diperlukan berbagai kebijakan dibidang ekonomi termasuk sektor perbankan, sehingga diharapkan akan dapat memperbaiki dan memperkokoh perekonomian nasional. 
Sektor perbankan yang memiliki posisi strategis sebagai lembaga intermediasi dan penunjang sistem pembayaran merupakan faktor yang sangat menentukan dalam proses pembangunan nasional dibidang ekonomi. Bank sebagai lembaga intermediasi dimaksudkan sebagai perantara pihak-pihak yang mempunyai kelebihan dana (surplus of fund) dengan pihak-pihak yang kekurangan dan memerlukan dana (lack of fund). Jadi dengan demikian perbankan akan bergerak dalam kegiatan perkreditan dan berbagai jasa yang diberikan, bank melayani kebutuhan pembiayaan serta melancarkan sistem pembangunan bagi semua sektor perekonomian. ${ }^{1}$

Pembangunan dalam pengertian terbatas bertujuan untuk mencapai kesejahteraan baik lahir maupun batin setiap warga Negara, salah satu tujuannya adalah untuk mewujudkan kesejahteraan hidup setiap warga negra dan masyarakatdalam kondisi yang layak, seimbang baik menyangkut kebutuhan spiritual maupun material. Hal tersebut selaras dengan tujuan pembangunan nasional yaitu menciptakan masyarakat adil dan makmur, sejahtera baik lahir maupun batin.

Dalam hubungannya dengan kesejahteraan lahir maupun batin maka setiap orang memerlukan tempat tinggal yaitu sebuah rumah yang layak. Karena rumah merupakan salah satu kebutuhan dasar manusia dan merupakan factor penting dalam peningkatan harkat dan martabat hidup setiap orang. Dalam memenuhi kebutuhan perumahan tersebut, seseorang memerlukan dana dalam bentuk uang

\footnotetext{
${ }^{1}$ Muhammad Djumhana, Hukum Perbankan di Indonesia, Citra Aditya Bakti, Bandung, 2000, hal. 1
}

tunai, sedangkan uang tunai yang dimiliknya terbatas, sehingga orang tersebut berusaha mengajukan pinjaman atau permohonan kredit kepada bank, karena kebutuhan manusia yang beraneka ragam dan semakin meningkat sedangkan kemampuan untuk mencapai sesuatu yang diinginkan tersebut terbatas.

Kredit yang disalurkan oleh bank merupakan kepercayaan yang diberikan kepada debitur untuk pembiayaan, konsumtif dan usaha yang pembayaran atau pelunasannya diatur dengan syarat-syarat dan kesepakatan bersama didalam bentuk perjanjian kredit. Kredit dalam kegiatan perbankan merupakan kegiatan usaha yang paling utama karena pendapatan terbesar dari usaha bank berasal dari pendapatan kegiatan usaha kredit yang berupa bunga dan provisi.

Suatu kredit baru diluncurkan setelah ada suatu kesepakatan tertulis, walaupun mungkin dalam bentuk yang sangat sederhana antara pihak kreditur sebagai pemberi kredit dengan pihak debitur sebagai penerima kredit. Kesepakatan tertulis ini sering disebut dengan perjanjian kredit (credit agreement, loan agreement). ${ }^{2} \quad$ Setelah pembuatan perjanjian kredit dilanjutkan dengan perjanjian pengikatan jaminan.

Menurut Undang-undang Nomor 10 Tahun 1998 tentang Perubahan atas Undang-undang Nomor 7 Tahun 1992 tentang Perbankan, dalam Pasal 1 angka 11 yang dimaksud dengan kredit adalah

Penyediaan uang atau tagihan yang dapat dipersamakan dengan itu, berdasarkan

${ }^{2}$ Munir Fuady, Hukum Perkreditan Kontemporer, PT. Citra Aditya Bakti, Bandung, 2002, hal. 31. 
persetujuan atau kesepakatan pinjam-meminjam antara bank dengan pihak lain yang mewajibkan pihak peminjam untuk melunasi hutangnya setelah jangka waktu tertentu dengan pemberian bunga.

Masalah penjaminan atas suatu hutang mempunyai arti yang sangat penting bagi kreditur, sebab suatu perikatan antara kreditur dan debitur ini, kreditur mempunyai kepentingan bahwa debitur harus memenuhi kewajiban. ${ }^{3}$ Jaminan atas hutang ini juga memberi makna adanya perlindungan kreditur yang telah melepaskan sejumlah uangnya yang digunakan sebagai modal oleh debitur dan sekaligus memberi kepastian hukum akan kembalinya sejumlah uangnya yang digunakan oleh debitur kepada kreditur. ${ }^{4}$

Begitu besar arti kedudukan benda jaminan ini bagi kreditur karena dengan benda jaminan ini bagi kreditur akan menimbulkan keyakinan bahwa debitur akan memenuhi segala kewajibannya atas sejumlah uang yang dipergunakan oleh debitur dan sekaligus dengan adanya benda jaminan, pemenuhan hak dan kewajiban serta adanya kepastian hukum dan segala perlindungan secara yuridis terpenuhi.

Berbeda dengan gadai, benda yang dibebankan dengan jaminan fidusia tidak diserahkan kepada penerima fidusia atau kreditur, melainkan tetap dalam penguasaaan fisik pemberi fidusia yaitu debitur atau pihak ketiga, karena jaminan

${ }^{3}$ Oey Hoey Tiong, fidusia Sebagai Jaminan Unsur-unsur, Penerbit Ghalia Indonesia, Jakarta, 1985, hal. 15

${ }^{4}$ Sri Sudewi Masjoen Sofwan, Beberapa Masalah Lembaga Jaminan khususnya Fidusia Dalam praktek dan pelaksanaannya di Indonesia, . Penerbit Liberty, Yogyakarta, 1981, hal. 2 ini bersifat kepercayaan. Tetapi penguasaan yuridis tetap berada di tangan penerima fidusia, karena terjadi pengalihan hak kepemilikan dari pemberi fidusia kepada penerima fidusia. Namun pengalihan hak kepemilikan ini beralih kembali apabila debitur dapat melunasi utangnya sesuai waktu yang diperjanjikan. ${ }^{5}$

Seperti jaminan kebendaan lain, maka penerima fidusia juga mempunyai hak preferent, yaitu hak untuk didahulukan pelunasan piutangnya dari kreditur lain terhadap benda fidusia. Apabila terdapat kelebihan dari hasil penjualan benda jaminan fidusia tersebut, maka penerima fidusia juga wajib mengembalikan kepada pemberi fidusia, karena biasanya nilai benda jaminan lebih besar dari jumlah utang dalm perjanjian kredit.

Jaminan Fidusia juga dapat membebankan piutang. Semula jaminan fidusia tidak diatur dalam Undang-undang, bahwa berdasarkan yurisprudensi, dan jaminan fidusia ini dulu dikenal dengan istilah Fiduciare Eigendom Overdracht, atau disingkat dengan FEO $^{6}$

Lembaga ini muncul disebabkan adanya rasa kebutuhan dari masyarakat sendiri, disamping pengaruh dari berlakunya UUPA ( Undang-Undang Nomor 5 tahun 1960 tentang Peraturan PokokPokok Agraria, yang lazim disebut Undang-Undang agraria). Dirasakan

\footnotetext{
${ }^{5}$ Ibid, hal 11

${ }^{6}$ Satrio. J, Hukum Jaminan Hak Jaminan Kebendaan, PT. Citra Aditya Bhakti, Bandung, 2002, hal 14.
} 
sesuai dengan kebutuhan masyarakat, karena prosedurnya lebih mudah, lebih luwes, biaya murah, selesainya cepat dan meliputi benda bergerak dan tidak bergerak. Namun untuk memjamin kepastian hukum serta mampu memberikan perlindungan hukum bagi pihak yang berkepentingan, lembaga fidusia ini tetap harus dituangkan dalam suatu peraturan yang jelas dan lengkap. Apalagi lembaga fidusia pada waktu itu tidak didaftarkan pada kantor Pendaftaran Fidusia, sehingga kedudukan kreditur sebagai kreditur konkuren bersama dengan krediturkreditur lainnya. Oleh karena itu dibentuklah Undang-Undang Nomor 42 tahun 1999 tentang Jaminan Fidusia yang berusaha menampung kebutuhan-kebutuhan tersebut. Jaminan yang diatur dengan lembaga fidusia ini boleh dikatakan mempunyai sifat khusus di mana kreditur tidak menguasai benda sebagai obyek jaminan, jadi di sini kita bicara tentang resiko yang akan timbul, maka resiko yang menjadi beban kreditur akan lebih besar dibanding dengan resiko yang ditanggung oleh kreditur.

Piutang sebagai benda obyek jaminan, hal ini juga memberikan keleluasaan baik bagi debitur maupun kreditur. Keuntungan bagi kreditur bisa mendapatkan modal bagi pengembangan usahanya dan bagi kreditur dengan adanya penyerahan piutang sebagai jaminan maka dengan sendirinya apabila debitur mengalami wanprestasi maka kreditur berhak atas semua piutang yang menjadi hak debitur dari pihak ketiga.

Dengan diundangkannya Undang-Undang nomor 42 tahun 1999 tentang fidusia, maka lembaga jaminan fidusia mempunyai landasan hukum yang jelas, artinya undang-undang ini akan memperjelas hak- hak dan kewajiban baik bagi kreditur maupun bagi debitur.

Di dalam undang-undang tersebut juga ditentukan adanya kewajiban untuk mendaftarkan akta perjanjian fidusia ke kantor pendaftaran fidusia, walaupun sebenarnya pendaftaran itu untuk pemenuhan asas publisitas akan tetapi di dalam undang-undang tersebut ditentukan bahwa pendaftaran merupakan syarat kelahiran jaminan fidusia yang diberikan oleh debitur kepada kreditur dengan pendaftaran akta penjaminan fidusia atau pada saat lahirnya hak jaminan fidusia, maka hak-hak kreditur atas benda yang dijaminkan dengan lembaga jamian fidusia juga lahir dan hal ini akan melahirkan kreditur sebagai kreditur preferent.

Pendaftaran yang dilakukan di kantor pendaftaran fidusia sebetulnya ada 2 hal yang harus didaftar, yaitu pendaftaran benda yang dibebani oleh jaminan fidusia, pasal 11 ayat (1), ketentuan ini tentunya kan membawa akibat terhadap benda-benda yang didaftar oleh lembaga lain apabila harus didaftar ulang. Sedangkan menurut pasal 13 ayat (1) juncto pasal 14 ayat 1 dan 2 , pasal 15 ayat 1 dan 2 dan pasal 16 ayat 1 , pendaftaran yang dimaksud adalah pendaftaran akta pemberian jaminan yang dibuat oleh notaris saja.

Sedangkan benda jaminan fidusia tidak didaftar akan tetapi hanya disebutkan pada sertifikat jaminan fidusia saja. Kewajiban untuk mendaftarkan akta fidusia merupakan hak dan kewajiban kreditur dalam perkembangan pelaksanaannya mengingat tempat 
pendaftaran fidusia hanya di ibukota propinsi dan biaya yang harus dikeluarkan untuk melaksanakan pendaftaran maka kreditur cukup membuat akta kuasa memasang fidusia. Hal ini tidak ditur oleh undang-undang dan undang-undang tidak melarangnya akan tetapi pembuatan kuasa memasang fidusia tidak akan menimbulkan hak preferent bagi kreditur dan hal ini tidak memenuhi asas publisitas, upaya-upaya pembuatan kuasa memasang fidusia tidak memenuhi asas publisitas sebagaimana yang ditentukan dalam Undang-Undang Fidusia jadi apabila deitur wanprestasi dan fidusia tersebut belum dibuat akta pemberian jaminan fidusia apalagi belum didaftarkan ke kantor pendaftaran fidusia, maka kedudukan kreditur adalah tetap sebagai kreditur konkuren bukan sebagai kreditur preferent. $^{7}$

Dalam hal pelaksanaan kredit dengan jaminan Fidusia, yaitu dalam pelaksanaannya perjanjian kredit dengan jaminan fidusia dilakukan dengan perjanjian dibawah tangan dan tidak diikuti dengan pendaftaran di Kantor Pendaftaran Fidusia, hal ini secara kongkrit dapat menimbulkan problem jika debitur wanprestasi. ${ }^{8}$

\section{A. Perumusan Masalah}

$$
\begin{aligned}
& \text { Berdasarkan uraian di atas, } \\
& \text { maka permasalahannya dapat } \\
& \text { dirumuskan sebagai berikut: } \\
& \text { 1. Bagaimana pelaksanaan kredit } \\
& \text { dengan jaminan Fidusia Menurut } \\
& \text { Undang-Undang No. } 42 \text { Tahun } \\
& 1999
\end{aligned}
$$

2. Bagaimana penyelesaian jika

\footnotetext{
${ }^{7}$ Ibid, hal 21

${ }^{8}$ Budi Untung.H, Kredit Perbankan Indonesia, Penerbit Andi, Yogyakarta, 2000, hal 38
}

terjadi debitur wanprestasi dalam perjanjian kredit jaminan fidusia

\section{Tujuan dan manfaat penelitian}

1. Tujuan penelitian

a. Untuk mengetahui bagaiman pelaksanaan kredit dengan jaminan Fidusia Menurut Undang-Undang No. 42 Tahun 1999

b. Untuk mengetahui penyelesaian terhadap debitur wanprestasi dalam perjanjian kredit jaminan fidusia

2. Manfaat Penelitian

a. Secara teoritis

Penelitian ini dapat diharapkan dapat memberikan sumbangan pemikiran terhapap pengetahuan di bidang ilmu hukum umumnya dan hukum perdata pada khususnya hukum jaminan fidusia.

Penelitian ini diharapkan dapat berguna bagi peneliti dan bahan bacan di perpustakaan dan sebagai bahan acuan untuk penelitian lanjutan yang akan datang mengenai hukum jaminan atau hukum perjanjian kredit pada umumnya.

b. Secara praktis

Penelitian ini diharapkan dapat memberikan sumbangan pemikiran dalam kegiatan usaha/perusahaan, serta masyarakat, pelaku usaha yang khususnya berkecimpung dalam dunia perbankan/dunia usaha, dan juga sebagai bahan kajian para akademis dalam menambah wawasan pengetahuan terutama dalam bidang perjanjian kredit dengan jaminan fidusia

\section{Metode penelitian}

Tipe penelitian penelitian hukum doktrinal atau yang lebih dikenal dengan penelitian hukum 
normatif yang disebut juga yuridis normatif (legal research) adalah penelitian yang dilakukan dengan mengkaji dan menganalisis substansi peraturan perundang- undangan atas pokok permasalahan atau isu hukum dalam konsistensinya dengan asasasas hukum yang ada. Dengan pendekatan tersebut, peneliti akan mendapatkan informasi dari berbagai aspek mengenai isu hukum yang sedang dihadapi. Pendekatan undangundang (statue approach) dilakukan dengan menelaah peraturan perundangan berlaku khususnya tentang hukum perbankan, hukum jaminan yaitu mengenai Penyelesaian Debitur Wanprestasi Dalam Perjanjian Kredit Jaminan Fidusia Menurut Undang-Undang Nomor 42 Tahun 1999 Tentang Jaminan Fidusia.

Dalam penulisan dengan data primer dan sekunder diperoleh dari bahan-bahan kepustakaan yang berupa Undang-Undang, yaitu Undang-Undang No. 42 Tahun 1999 tentang Jaminan Fidusia, UndangUndang No. 10 Tahun 1998 tentang Perbankan, KUH Perdata, KUH Dagang dan literatur-literatur, bahan perkuliahan serta sumber lainnya yang berhubungan dengan perjanjian kredit dengan jaminan fidusia dan permasalahan pada khususnya.

\section{PEMBAHASAN}

\section{Pelaksanaan Perjanjian kredit Jaminan Fidusia}

Pemberian kredit dengan jaminan fidusia pada bank selain sebagai salah satu mencari keuntungan bertujuan untuk membantu masyarakat yang memerlukan dana untuk modal kerja, dengan dana tersebut diharapkan masyarakat dapat mengembangkan usahanya. Mekanisme pemberian kredit dengan jaminan fidusia ini dilakukan dengan memegang prinsip kehati- hatian, pemberian kredit dengan jaminan fidusia ini lebih kepada faktor kepercayaan, bonafiditas dan prospek dari kegiatan usaha debitur.

Mengingat pentingnya

kedudukan dana perkreditan tersebut sudah semestinya apabila pemberi dan penerima kredit serta pihak lain yang terkait mendapat perlindungan melalui suatu lembaga hak jaminan yang kuat serta memberikan kepastian hukum bagi pihak yang berkepentingan. Faktor penting yang harus diperhatikan untuk mengurangi resiko adalah keyakinan atas kemampuan dan kesanggupan debitur untuk melunasi hutangnya sesuai dengan yang diperjanjikan. Untuk memperoleh keyakinan tersebut, sebelum memberikan kredit bank harus melakukan penilaian yang seksama terhadap watak kemampuan, modal, agunan dan prospek usaha debitur.'

Oleh karena itu bank harus mempunyai kebijakasanaan kredit yang mencakup komposisi dan pengendalian portopolio kredit secara menyeluruh dan memuat standar yang berlaku untuk setiap pengambilan keputusan dalam pemberian kredit. Selain itu pelaksanaan kredit harus memiliki standar yang mengandung unsur pengawasan kredit yag dapat memantau kualitas pemberian kredit pada semua tahapan dalam proses pemberian kredit. Kebijaksanaan kredit juga harus memuat metode untuk memelihara cadangan yang cukup atas aktiva yang diklasifikasi. ${ }^{10}$

\footnotetext{
${ }^{9}$ Ibid, hal. 40

${ }^{10}$ Kasmir, SE. MM, Dasar-Dasar
} Perbankan., PT Raja Grafindo Persada, Jakarta, 2002, hal 47 
Pada dasarnya dalam pelaksanaan prosedur pemberian kredit dengan jaminan fidusia sama dengan prosedur pemberian kredit dengan jaminan yang lain, namun khusus untuk kredit dengan jaminan fidusia setelah melalui tahapan prosedur pemberian kredit, jaminan fidusia itu harus dibuatkan akta fidusia di Notaris dan kemudian harus didaftarkan di Kantor Pendaftaran Fidusia. Hal ini bertujuan agar memberikan kepastian hukum bagi para pihak.

Setelah melalui prosedur pemberian kredit dengan jaminan fidusia Bank tersebut di atas, yang harus dilakukan selanjutnya adalah membuat Akta Jaminan Fidusia. Akta Jaminan Fidusia tersebut dibuat oleh Notaris. Sebelum diserahkan kepada notaris untuk dibuatkan Akta Jaminan Fidusia, pihak Bank harus menyerahkan berkas pembuatan akta fidusia kepada Notaris, yang berisikan dari berkas permohonan pembuatan Akta Fidusia adalah:

1. Identitas pemberi jaminan fidusia;

2. Identitas penerima jaminan fidusia;

3. Identifikasi obyek jaminan. Jaminan kredit berfungsi sebagai pengamanan atas pengembalian kredit. didalam Undang-undang Perbankan yaitu Undang-Undang Nomor 10 Tahun 1998 tidak mensyaratkan pemberian kredit harus diikuti dengan jaminan, namun dalam pelaksanaannya bank tetap meminta jaminan dari pemohon kredit, disamping melakukan analisis terhadap itikad baik dan keadaan usaha permohonan kredit. Jaminan kredit umumnya adalah jaminan kebendaan, yang dapat berupa benda tetap maupun benda bergerak yang nilainya mencukupi untuk menjamin kredit. ${ }^{11}$

Jaminan kredit yang dapat diterima bank pada umumnya adalah jaminan kebendaan, baik benda tetap yang dibebani dengan hak tanggungan maupun benda bergerak yang dijaminkan secara fidusia. Penyerahan jaminan fidusia dilakukan berdasarkan kepercayaan (constitutum possessorium), sehingga yang diserahkan debitur kepada kreditur bukanlah bendanya, tetapi hak kepemilikannya, dengan demikian maka benda jaminan fidusia tersebut masih berada dalam kekuasaan debitur.

Menurut undang-undang, jaminan fidusia dianggap lahir setelah dicatatnya jaminan fidusia kedalam Buku Daftar Fidusia. Selanjutnya Kantor Pendaftaran Fidusia akan mengeluarkan Sertifikat Jaminan Fidusia dan diberikan kepada pihak yang mendaftarkan jaminan Fidusia. Sertifikat Jaminan Fidusia tersebut memuat hak preferen bagi pemegangnya, yaitu hak untuk diutamakan pemenuhan piutangnya dari penjualan objek jaminan fidusia tersebut dari kreditur lain. ${ }^{64}$

Pembebanan jaminan fidusia yang tidak mengikuti ketentuan undang-undang, tidak mendapatkan perlindungan hukum. Kedudukan penerima fidusia dalam hal ini bukan sebagai kreditur preferen, sedangkan pemberi fidusia juga tidak mendapatkan perlindungan hukum sebagaimana tercantum

\footnotetext{
${ }^{11}$ Muhammad Djumhana, Hukum Perbankan di Indonesia, Penerbit PT Citra Adiya Bhakti, Bandung, 2000, hal. 32.
} 
dalam Pasal 4 jo Pasal 25 Undang-Undang Nomor 42 Tahun 1999 Tentang Jaminan Fidusia. ${ }^{12}$

$$
\text { Bank dalam hal ini }
$$

beranggapan bahwa dengan perjanjian dibawah tangan dan adanya surat kuasa substusi untuk pendaftaran fidusia yang penandatanganan perjanjian tersebut di depan notaris sudah cukup untuk melakukan tindakan hukum apabila di kemudian hari Debitur wanprestasi.

Menurut ketentuan Pasal 20 dan Pasal 21 Undang-undang Nomor 42 Tahun 1999 tentang Jaminan Fidusia dalam hal debitur pemberi fidusia cidera janji maka bank.' berkedudukan sebagai kreditur preferen yang berhak diutamakan pelunasan piutangnya dari hasil penjualan objek jaminan fidusia tersebut.

\section{Penyelesaian kredit debitur wanpreatasi dalam perjanjian kredit jaminan fidusia \\ Debitur yang tidak} memenuhi kewajibannya karena ada kesalahan disebut wanprestasi, sedangkan kalau tidak ada kesalahan debitur, maka terjadi overmacht (force majeure, keadaan memaksa). ${ }^{13}$

Dari bentuk-bentuk wanprestasi ini, kadang-kadang menimbulkan keraguan untuk menentukan bentuk yang mana debitur yang melakukan wanprestasi. Apabila debitur sudah tidak mampu memenuhi prestasinya, maka termasuk pada bentuk pertama, sedangkan apabila debitur masih memenuhi prestasinya, maka dianggap sebagai

\footnotetext{
${ }^{12}$ Ibid, hal 35.
}

${ }^{13}$ Sigit Irianto, Asas-asas Huku Perikatan (Perikatan yang Lahir Dari Perjanjian), PT Raja Grafindo Persada, Jakarta, 2002. hal. 20 terlambat dalam memenuhi prestasi. Apabila debitur memenuhi prestasi tidak sebagaimana mestinya atau keliru dalam memenuhi prestasinya, maka ada dua kemungkinan yaitu apabila masih dapat diharapkan untuk diperbaiki, maka dianggap terlambat memenuhi prestasi, dan apabila tidak dapat diharapkan lagi maka dianggap debitur tidak dapat memenuhi prestasi sama sekali.

$$
\text { Debitur yang tidak }
$$

memenuhi kewajibannya karena ada kesalahan disebut wanprestasi, sedangkan kalau tidak ada kesalahan debitur, maka terjadi overmacht (force majeure, keadaan memaksa). ${ }^{14}$

Luasnya kesalahan

meliputi kesengajaan, yaitu perbuatan itu memang diketahui dan dikehendaki dan kelalaian yaitu tidak mengetahui tetapi hanya mengetahui adanya kemungkinan bahwa akibatnya akan terjadi kesengajaan ini dalam undangundang disebut dengan arglist (Pasal 1247 dan 1248 KUH Perdata). Untuk menentukan apakah seorang debitur itu bersalah melakukan prestasi, maka ada tiga bentuk wanprestasi, yaitu

1. Debitur tidak memenuhi prestasi sama sekali,

2. Debitur terlambat dalam memenuhi prestasi; dan

3. Debitur berprestasi tidak sebagaimana mestinya ${ }^{71}$

Apabila setelah bank

berusaha melalui upaya prefentif namun akhirnya kredit yang telah dikeluarkannya menjadi kredit yang bermasalah, maka bank akan

\footnotetext{
${ }^{14}$ Gunawan Wjaya,dkk, Seri Hukum Bisnis Jaminan Fidusia, PT Raja Grafindo Persada, Jakarta, 2000, hal. 29
} 
menggunakan upaya represif. Upaya-upaya represif yang mulamula akan dilakukan ialah melakukan upaya penyelamatan kredit. Bila ternyata upaya penyelamatan kredit tidak dapat dilakukan atau walaupun sudah dilakukan tetapi tidak membawa hasil, maka bank akan menempuh upaya penagihan kredit.

a. Upaya penyelamatan kredit

Upaya bank untuk menyelamatkan kredit adalah upaya yang dilakukan untuk melancarkan kembali kredit yang sudah tergolong dalam kredit "tidak lancar", "diragukan" atau bahkan telah tergolong dalam "kredit macet" untuk kembali menjadi "kredit lancar" sehingga debitur kembali mempunyai kemampuan untuk membayar kembali kepada bank segala utangnya disertai dengan biaya dan bunga.

$\begin{array}{rrr} & \begin{array}{c}\text { Menurut Surat } \\ \text { Edaran }\end{array} \\ \text { Bank Indonesia } & \text { Nomor } \\ \text { 23/12/BPPP tanggal } 28 & \text { Pebruari } \\ \text { 1991, } & \text { upaya-upaya }\end{array}$
penyelamatan kredit yang dapat dilakukan oleh bank adalah sebagai berikut :

1. Penjadwalan kembali (Rescheduling), yaitu dengan melakukan perubahan syaratsyarat perjanjian kredit yang berhubungan dengan jadwal pembayaran kembali kredit atau jangka waktu kredit, termasuk grade period atau masa tenggang, baik termasuk perubahan besarnya jumlah angsuran atau tidak.

2. Persyaratan kembali
(Reconditioning), dengan melakukan perubahan atas sebagian atau seluruh syarat-syarat perjanjian kredit, yang tidak hanya terbatas pada perubahan jadwal angsuran dan atau jangka waktu kredit saja. Namun perubahan tersebut tanpa memberikan tambahan kredit atau tanpa melakukan konversi atas seluruh atau sebagian dari kredit menjadi perusahaan.

3. Penataan kembali (Restructuring) yaitu suatu upaya dari bank yang berupa melakukan perubahanperubahan syaratsyarat perjanjian kredit yang berupa pemberian tambahan kredit, atau melakukan konversi atas seluruh atau sebagian dari kredit menjadi equity perusahaan, yang dilakukan dengan atau tanpa Rescheduling dan atas Reconditioning. ${ }^{15}$

b. Penyelesaian kredit Menurut

pertimbangan pihak bank, kredit yang bermasalah tidak mungkin dapat diselamatkan untuk menjadi lancar kembali melalui upaya-upaya penyelamatan sebagaimana telah diuraikan di atas dan akhirnya kredit yang

15 Surat Edaran Bank Indonesia Nomor 23/12/BPPP tanggal 28 Pebruari 1991 


\begin{abstract}
bersangkutan menjadi kredit macet, maka bank akan melakukan tindakantindakan penyelesaian atau penagihan terhadap kredit tersebut. Adapun yang dimaksudkan dengan penyelesaian kredit macet atau penagihan kredit macet adalah upaya bank untuk memperoleh kembali pembayaran dari debitur atas kredit bank yang telah menjadi macet dengan menggunakan beberapa langkah, namun dalam hal ini penulis hanya akan menguraikan tentang penyelesaian kredit macet melalui eksekusi benda jaminan.

$$
\text { Pasal } 29 \text { Undang- }
$$

Undang Jaminan Fidusia menyatakan bahwa apabila debitur atau pemberi fidusia cidera janji, eksekusi terhadap benda yang menjadi objek jaminan fidusia dapat dilakukan dengan cara:
\end{abstract}

1. Pelaksanaan titel eksekutorial oleh penerima fidusia; Dalam Undang-Undang Jaminan Fidusia diatur secara khusus tentang eksekusi jaminan fidusia yaitu melalui parate eksekusi.

Parate eksekusi adalah melakukan sendiri eksekusi tanpa bantuan atau tanpa campur tangan pengadilan. Parate eksekusi dalam hukum jaminan semula hanya diberikan kepada kreditur penerima hipotik pertama dan kepada penerima gadai (pand).

Dalam
hukum jaminan terdapat
beberapa macam parate
eksekusi. Di antaranya:
parate eksekusi penerima
hipotik pertama, parate
eksekusi penerima hak
tanggungan pertama,
parate eksekusi penerima
gadai, parate eksekusi
penerima fidusia, parate
eksekusi Panitia Urusan
Piutang Negara (PUPN)
untuk bank Pemerintah.

2. Penjualan benda yang menjadi objek jaminan fidusia atas ekuasaan penerima fidusia sendiri melalui pelelangan umum serta mengambil pelunasan piutangnya dari hasil penjualan;

Pada prinsipnya adalah bahwa penjualan benda yang menjadi objek jaminan fidusia harus melalui pelelangan umum, karena dengan cara ini diharapkan dapat diperoleh harga yang paling tinggi. Namun demikian dalam hal penjualan melalui pelelangan umum diperkirakan tidak akan menghasilkan harga tertinggi yang menguntungkan baik pemberi fidusia ataupun penerima fidusia, maka dimungkinkan penjualan di bawah tangan asalkan hal tersebut disepakati oleh pemberi fidusia dan penerima fidusia dan syarat jangka waktu pelaksanaan penjualan tersebut dipenuhi.

3. Penjualan di bawah tangan 


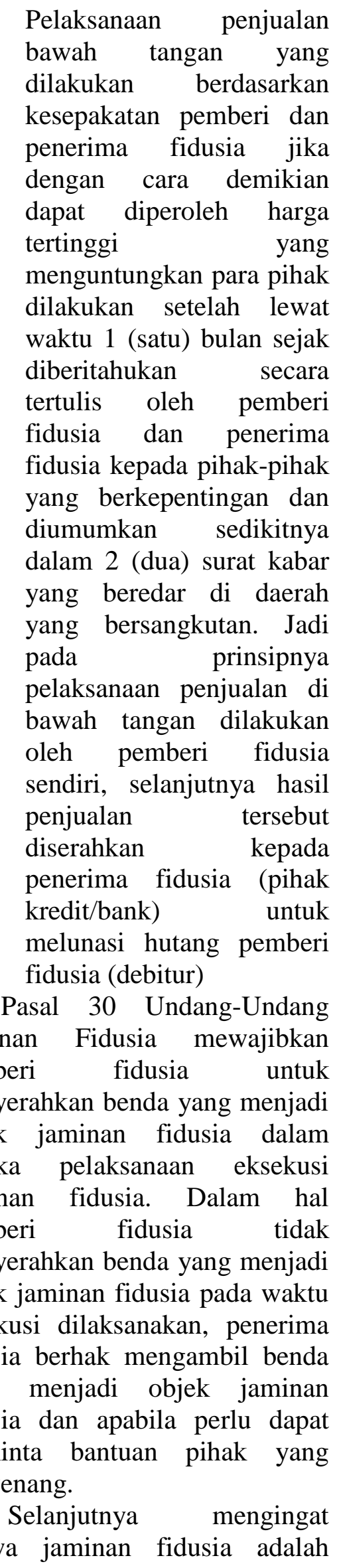

pranata jaminan dan bahwa pengalihan hak kepemilikan dengan cara constitutum prossessorium adalah dimaksudkan semata- mata untuk memberi agunan dengan hak yang didahulukan kepada penerima fidusia, maka sesuai dengan Pasal 33 Undang-Undang Jaminan Fidusia setiap janji yang memberi kewenangan kepada penerima fidusia untuk memiliki benda yang menjadi objek jaminan '"fidusia apabila debitur cidera janji, batal demi hukum.

Ketentuan tersebut dibuat untuk melindungi pemberi fidusia, teristimewa jika nilai objek jaminan fidusia melebihi besarnya utang yang dijamin. Sesuai dengan Pasal 34 Undang-undang Jaminan Fidusia, dalam hal hasil eksekusi melebihi nilai penjaminan, penerima fidusia wajib mengembalikan kelebihan tersebut kepada pemberi fidusia. Namun demikian apabila hasil eksekusi tidak mencukupi untuk pelunasan utang, debitur tetap bertanggung jawab atas utang yang belum terbayar.

Di samping itu, sesuai dengan ketentuan Pasal 21 ayat (4) Undang- undang 42 Tahun 1999 tentang Jaminan Fidusia, maka hasil pengalihan atau tagihan yang timbul karena pengalihan demi hukum menjadi objek jaminan fidusia pengganti dari objek jaminan fidusia yang dialihkan. Bank juga akan meminta agar semua kuitansi penagihan, dan hasil pengalihan/penjualan dari benda jaminan tersebut sebagai objek jaminan fidusia pengganti, pada tahap inilah sebenarnya letak kelemahan jaminan fidusia. Dalam kasus ini, bagi debitur 
nakal akan mudah untuk melakukan penipuan terhadap benda jaminan fidusia tersebut, seperti menjual dan hasil penjualannya dialihkan kepada usaha lain. ${ }^{16}$

Kredit

bermasalah merupakan suatu risiko yang sangat mungkin terjadi dalam pemberian kredit dan merupakan gejala yang harus diwaspadai oleh setiap bank sebagai pemberi kredit. Menurut Surat Keputusan Direksi Bank Indonesia Nomor 31/147/ DIR tanggal 12 November 1998 tentang Kualitas Aktiva Produktif, yang termasuk kedalam golongan kredit bermasalah atau Non Performing Loan (NPL) adalah kredit dalam kategori kurang lancar, kredit yang diragukan dan kredit macet.

Kredit bermasalah pada umumnya disebabkan adanya tunggakan kredit, karena debitur tidak dapat melaksanakan kewajibannya membayar angsuran kredit, tepat pada waktunya sebagaimana telah diperjanjikan dalam perjanjian kredit.

\section{PENUTUP}

1. Dalam pemberian kredit dengan jaminan fidusia melalui tahapan prosedur permohonan kredit dan dibuatnya akta fidusia di notaris yang didaftarkan ke Kantor Pendaftaran Fidusia unutk memberikan kepastian hukum bagi kreditur (bank).

2. Proses penyelesaian kredit jika debitur wanpreatasi maka bank berdasarkan surat kuasa substitusi dari debitur dibuat akte Fidusia notariil dan didaftarkan ke Kantor Fidusia

16 Penjelasan UU No. 42 Tahun 1999 tentang Jaminan Fidusia

\begin{abstract}
yaitu debitur melakukan penjualan di bawah tangan, penjualan jaminannya secara sukarela, yang hasilnya diserahkan kepada bank untuk melunasi kredit tersebut, bank dapat melakukan pelelangan secara umum dan melalui lembaga Pengadilan.
\end{abstract}

\section{DAFTAR PUSTAKA}

Buku :

Budi Untung.H, Kredit Perbankan Indonesia, Penerbit Andi, Yogyakarta, 2000

Gunawan Wjaya dan Ahmad Yani,Seri Hukum Bisnis Jaminan Fidusia, PT Raja Grafindo Persada, Jakarta, 2000

Kasmir, SE. MM, Dasar-Dasar Perbankan., PT Raja Grafindo Persada, Jakarta, 2002

Muhammad Djumhana, Hukum Perbankan di Indonesia, Citra Aditya Bakti, Bandung, 2000

Munir Fuady, Hukum Perkreditan Kontemporer, PT. Citra Aditya Bakti, Bandung, 2002

Oey Hoey Tiong, fidusia Sebagai Jaminan Unsur-unsur, Penerbit Ghalia Indonesia, Jakarta, 1985,

Satrio. J, Hukum Jaminan Hak Jaminan Kebendaan, PT. Citra Aditya Bhakti, Bandung, 2002

Sigit Irianto, Asas-asas Huku Perikatan (Perikatan yang Lahir Dari Perjanjian), PT Raja Grafindo Persada, Jakarta, 2002

Sri Sudewi Masjoen Sofwan, Beberapa Masalah Lembaga Jaminan khususnya Fidusia Dalam praktek dan pelaksanaannya di Indonesia, . Penerbit Liberty, Yogyakarta, 1981

\section{Peraturan Perundang-undangan :}
a. Kitab Undang-Undang Hukum Perdata;
b. Undang-Undang No. 10 Tahun 1998 
Asuan, Penyelesaian Debitur Wanprestasi Dalam Perjanjian Kredit Jaminan Fidusia Menurut Undang-Undang No. 42 Tahun 1999 Tentang Jaminan Fidusia

Halaman 253-265

tentang Perbankan

c. Undang-Undang Nomor 42 Tahun

1999 tentang Jaminan Fidusia;

d. Surat Edaran Direktur Bank Indonesia

No. 26/22/Kep/Dir;

e. Surat Edaran Bank Indonesia No.

26/4/BPPP/1993; 